\title{
Хірургічне лікування місцево-розповсюджених та рецидивних солідних пухлин черевної порожнини та заочеревинного простору з нефректомією ех vivo ex situ та аутотрансплантацією нирки
}

\author{
О. В. Васильев, С. С. Сікачьов, О. О. Квасівка, В. І. Копецький, Д. О. Чевердюк, \\ В. І. Дорожинський, Ю. В. Вітрук, О. Е. Стаховський, К. В. Копчак
}

Національний інститут раку, м. Київ

\section{Surgical treatment of the locally-spread and recurrent solid tumors of abdominal cavity and retroperitoneal space with nephrectomy ex vivo ex situ and renal autotransplantation}

\author{
O. V. Vasylyev, S. S. Sikachyov, O. O. Kvasivka, V. I. Kopetskyi, D. O. Cheverdyuk, \\ V. I. Dorozhynskyi, Yu. V. Vitruk, O. E. Stakhovskyi, K. V. Kopchak
}

National Cancer Institute, Kyiv

Peферат

Мета. Покращення результатів лікування хворих з місцево-розповсюдженими та рецидивними солідними пухлинами черевної порожнини та заочеревинного простору.

Матеріали і методи. За період з червня 2015 по січень 2018 р. в Національному інституті раку виконали комбіновані оперативні втручання з нефректомією 28 хворим 3 приводу первинних місцево-розповсюджених та рецидивних солідних пухлин черевної порожнини та заочеревинного простору.

Результати. У 5 із 28 пацієнтів виконали нефректомію ex vivo ex situ з аутотрансплантацією нирки, у 4 - успішно. Гостре ушкодження нирок спостерігали у 6 (26\%) хворих, яким аутотрансплантації нирки не виконували. Після операції померли 2 (8,7\%) хворих. У паціентів, яким нирка була збережена, не спостерігали гострого ушкодження нирок, ніхто 3 цих пацієнтів не помер.

Висновки. 3 метою профілактики розвитку гострого ушкодження та хронічної хвороби нирок у майбутньому можливість виконання аутотрансплантації нирки у разі хірургічного лікування солідних пухлин черевної порожнини та заочеревинного простору, окрім первинного раку нирки, повинна бути розглянута щодо кожного хворого. Дану процедуру доцільно виконувати в спеціалізованих лікувальних закладах, де накопичено досвід в онковаскулярній хірургії.

Ключові слова: нефректомія ex vivo ex situ; аутотрансплантація нирки; гостре ушкодження нирок; солідні пухлини черевної порожнини та заочеревинного простору.

Abstract

Objective. Improvement of the treatment results in patients with the locally-spread and recurrent solid tumors of abdominal cavity and retroperitoneal space.

Materials and methods. From June 2015 till January 2018 yrs in National Cancer Institute the combined operative interventions with nephrectomy were conducted to 28 patients, suffering primary locally-spread solid tumors of abdominal cavity and retroperitoneal space.

Results. In 5 of 28 patients a nephrectomy ex vivo ex situ with renal autotransplantation were performed, of then in 4 - successfully. An acute renal injury was observed in $6(26 \%)$ patients, in whom renal autotransplantation was not conducted. After the operation 2 (8.7\%) patients died. In the patients, in whom a kidney was preserved, an acute renal injury was not observed, nobody of these patients died.

Conclusion. In future in every patient, undergoing surgical treatment of solid tumors of abdominal cavity and retroperitoneal space, besides primary renal cancer, a possibility of a renal autotransplantation performance must be considered for prevention of an acute injury and in chronic renal disease. This procedure is expedient to perform in specialized centers, were the oncovascular surgery experience is accumulated.

Keywords: nephrectomy ex vivo ex situ; renal autotransplantation; acute renal injury; solid tumors of abdominal cavity and retroperitoneal space.

Хірургічне втручання є ключовим у комплексній терапії злоякісних солідних пухлин черевної порожнини та основним методом лікування неорганних пухлин заочеревинного простору через їх резистентність до хіміотерапії та променевої терапії [1 - 4]. Місцево-розповсюджені пухлини зазвичай потребують виконання мульти- вісцеральної резекції для досягнення R0-статусу. 3 приводу пухлин з інвазією структур воріт нирки, як правило, виконують нефректомію. За даними світової літератури істинної інвазії заочеревинних неорганних пухлин у структури нирки не виявляють у 73\% хворих [5], у решти пацієнтів виникає необхідність у виконанні нефректо- 
міі. Радикальність хірургічного втручання може бути досягнута органозберігаючою резекцією капсули нирки без негативного впливу на віддалені результати [6]. У разі необхідності видалення нирки єдиним блоком з пухлиною без макроскопічних ознак інвазії та за збереженої функціональної здатності нирки за даними доопераційного обстеження є можливість виконати нефректомію ех vivo ex situ та аутотрансплантацію нирки.

Мета дослідження: покращення результатів лікування хворих 3 місцево-розповсюдженими та рецидивними солідними пухлинами черевної порожнини та заочеревинного простору, яким показано виконання нефректоміі.

\section{матеріали і методи дослідження}

За період з червня 2015 по січень 2018 р. в Національному інституті раку виконали комбіноване оперативне втручання з нефректомією з приводу первинних місцево-розповсюджених та рецидивних солідних пухлин черевної порожнини та заочеревинного простору 28 хворим. Жінок було 15 (53,6\%), чоловіків - 13 (46,4\%). Вік хворих коливався від 21 до 73 років, середній вік становив 53 роки. Клініко-патологічна характеристика пухлин представлена в таблищі.

Видалення пухлини, окрім нефректомії, комбінували 3 адреналектомією (у 9 хворих), резекцією товстої кишки (у

\begin{tabular}{|lcc|}
\hline \multicolumn{1}{|c|}{ Клініко-патологічна характеристика пухлин } \\
\hline \multicolumn{1}{|c|}{ Нозологічна форма } & \multicolumn{2}{c|}{ Кількість хворих } \\
\cline { 2 - 3 } & абс & $\%$ \\
\hline $\begin{array}{l}\text { Неорганні пухлини заочеревинного } \\
\text { простору }\end{array}$ & 18 & 64,3 \\
\hline $\begin{array}{l}\text { Первинний та рецидивний } \\
\text { колоректальний рак }\end{array}$ & 4 & 14,3 \\
\hline Рецидиви гінекологічних пухлин & 3 & 10,7 \\
\hline $\begin{array}{l}\text { Місцево-розповсюджені пухлини } \\
\text { наднирників }\end{array}$ & 2 & 7,1 \\
\hline $\begin{array}{l}\text { Місцево-розповсюджений рак тіла } \\
\text { та хвоста підшлункової залози }\end{array}$ & 1 & 3,6 \\
\hline
\end{tabular}

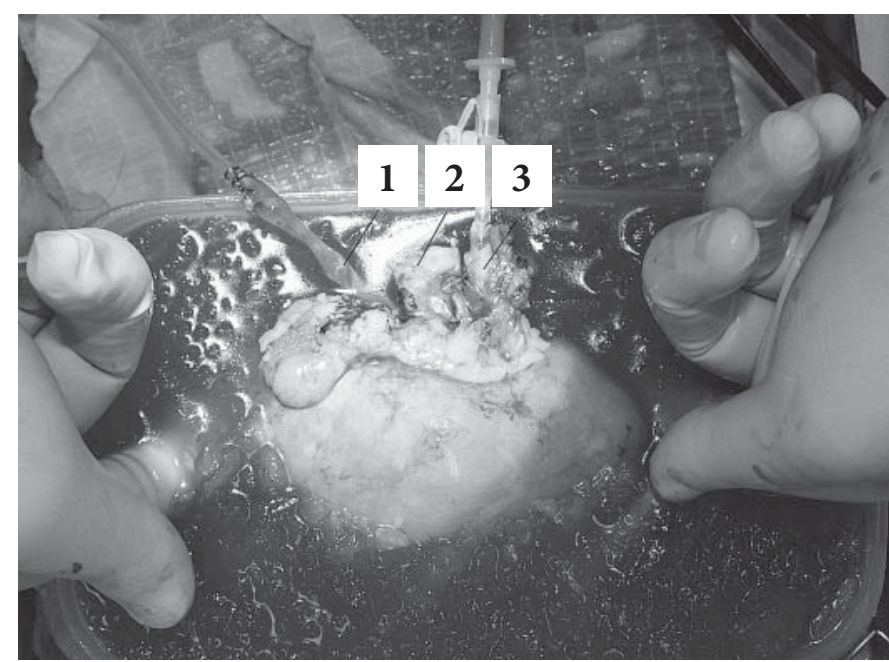

Puc. 1.

Eman Ha back table:

1 - сечовід; 2 - ниркова вена;

3 - канюльована ниркова артерія.
10), спленектомією (у 7), резекцією магістральних судин (у 7), резекцією підшлункової залози (у 6), резекцією дванадцятипалої кишки або дуоденоєюнального переходу (у 5), резекцією тонкої кишки (у 4), резекцією шлунка (у 3), резекцією печінки (у 3), парааортальною лімфодисекцією (у 3), латеральною розширеною внутрішньотазовою резекцією (у 2).

Усім хворим перед оперативним втручанням проведено мультиспіральну комп'ютерну томографію з внутрішньовенним контрастуванням та магнітно-резонансну томографію, за результатами яких планували об'єм оперативного втручання, можливість виконання аутотрансплантації нирки. Кандидатами для хірургічного лікування вважали хворих, у яких було можливим досягнення R0-статусу та які пройшли мультидисциплінарну онкологічну комісію. Функціональну здатність нирок оцінювали шляхом проведення динамічної реносцинтиграфії, ізостенуричний тип кривої вважали показанням до нефректомії. Можливість аутотрансплантації нирки розглядали у разі збереження іiі мінімальної функціональної здатності та відсутності інвазії пухлини у ворота нирки.

У всіх спостереженнях органокомплекс з пухлиною видаляли єдиним блоком. Плануючи аутотрансплантацію, на препараті маркірували ниркові судини. Препарат одразу після видалення переміщували на окремий стерильний стіл (back table), де в умовах гіпотермії в просвіт ниркової артерії вводили канюлю, через яку закачували охолоджений розчин НТК (гістидин-триптофан-кетоглутарат) (рис. 1). Процедуру вважали адекватною у разі витікання розчину через ниркову вену та зміни кольору паренхіми нирки. Одночасно нирку виділяли з тканин пухлини. Макроскопічно підтверджували відсутність інвазіі пухлини в паренхіму нирки, допускаючи інвазію в капсулу нирки. Проводили підготовку ниркових судин до формування анастомозів.

Паралельно інша бригада хірургів проводила підготовку до гетеротопічної аутотрансплантації: формували ложе в одній із клубових ямок, виділяли загальні здухвинні судини, за необхідності для їх кращої мобільності

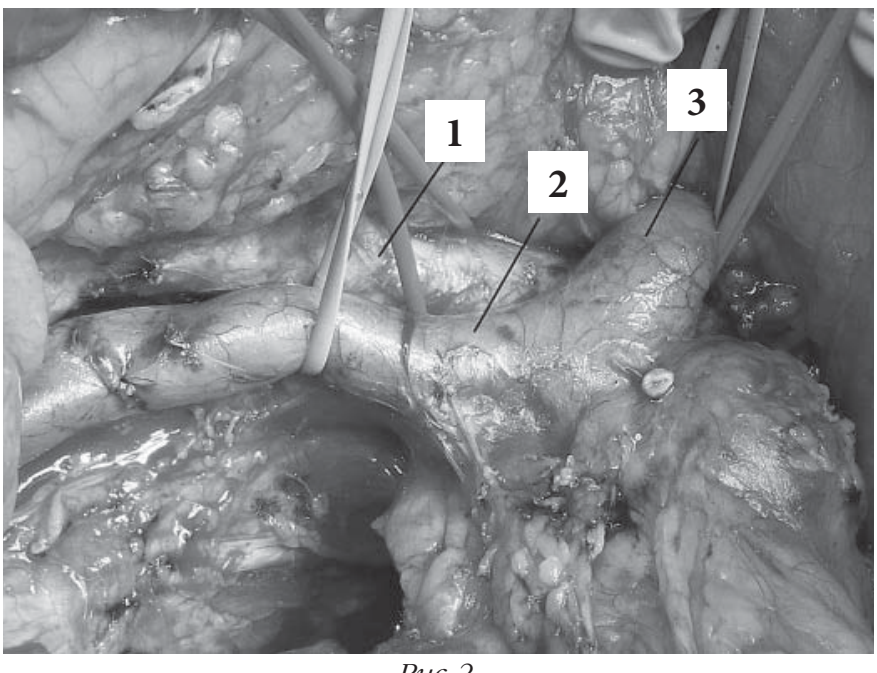

Puc.2.

Підготовлене ложе в клубовій ямиі для гетеротопічної аутотрансплантащій: 1 - права загальна здухвинна артерія; 2 - права загальна здухвинна вена; 3 - нижня порожниста вена. 


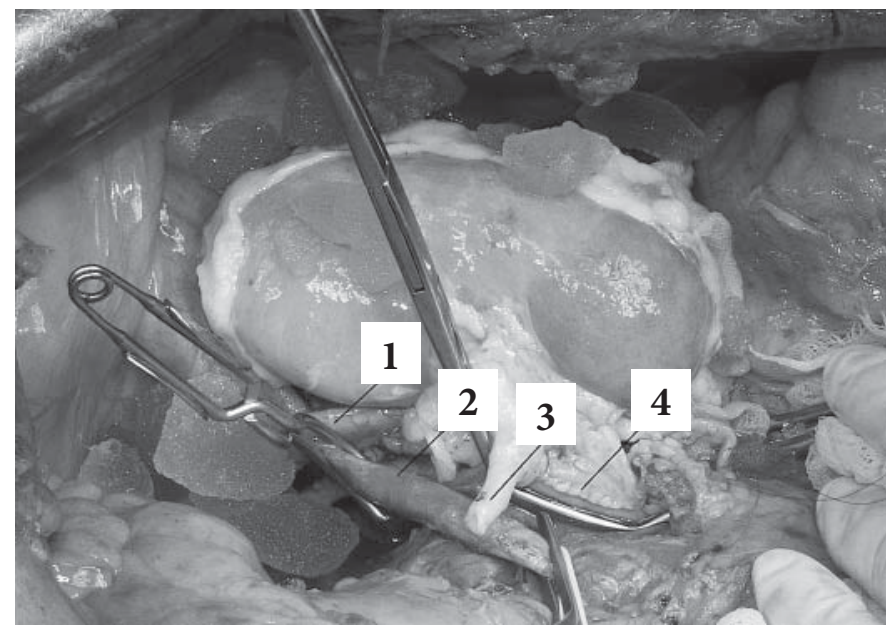

Puc.3.

Етап формування судинних анастомозів:

1 - сечовід; кукса ниркової артеріӥ (3) підготовлена до формування судинного анастомоза із загальною здухвинною артерією (2). Сформований судинний анастомоз кінець у бік (4) між нирковою та правою загальною здухвинною венами.

прошивали та пересікали внутрішні здухвинні судини з іпсилатеральної сторони (рис 2). Формували прямі судинні анастомози кінець у бік між нирковими та загальними здухвинними судинами, за необхідності використовували аутовенозні вставки (рис. 3). У просвіт кукси сечовода вводили канюлю із сечоприймачем для контролю темпу діурезу. Після відновлення ниркового кровотоку оцінювали життєздатність нирки: відсутність поширених зон ішемії та/або конгестії, наявність діурезу. Підтвердивши життездатність нирки, виконували уретероцистонеостомію за прийнятою в клініці стандартною методикою.

\section{Результати}

Комбіноване видалення пухлини з нефректомією виконали 28 хворим, яких розділили на дві групи: 1-ша група - 23 хворих, яким виконали нефректомію без аутотрансплантації, 2-га група - 5 хворих, яким виконали аутотрансплантацію нирки, що була успішною у 4 (14\%) хворих. Одній хворій 2-ї групи виконали аутотрансплантацію нирки зі складною артеріальною реконструкцією (рис. 4) у зв'язку з інвазією пухлини у структури воріт нирки, однак через тромбоз ниркової артерії нирка була видалена. Середня тривалість оперативного втручання в 1-й групі становила $(403 \pm 172)$ хв, у 2-й - (537 \pm 98$)$ хв, відмінність статистично незначуща (U=43, p=0,4027). Середній об'єм крововтрати в 1-й групі становив (895 \pm

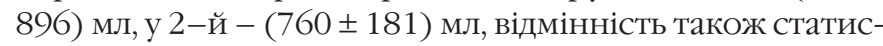
тично незначуща (U=43, p=0,4027).

Специфічне ускладнення у вигляді гострого ушкодження нирок розвинулося у 6 (26\%) хворих 1-ї групи, різниця між обома групами статистично незначуща $\left(\chi^{2}=1,7, \mathrm{p}\right.$ $>0,05)$. За даними доопераційного обстеження у всіх 6 хворих функціональна здатність обох нирок була в межах мінімально необхідної. За даними літератури у 5,5\% хворих після нефректомії або резекції нирки виникає гостре ушкодження нирок, що у свою чергу більше ніж у 4

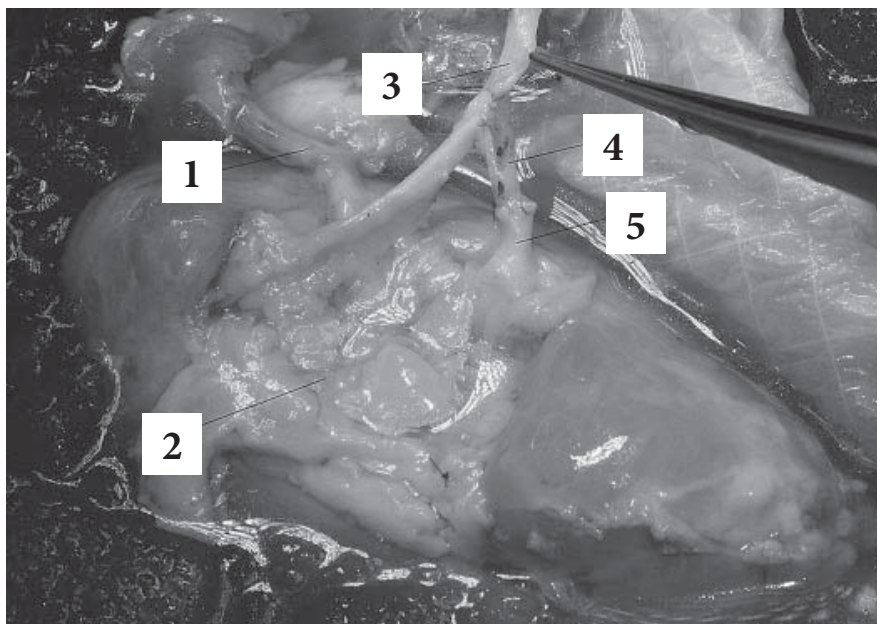

Puc. 4.

Eman Ha back table.

Нирка підготовлена до аутотрансплантащії: 1 -сечовід; 2 - ниркова вена. Сформовано анастомоз кінець у бік

між верхнъополюсною (5) та нижнъополюсною (3) нирковими артеріями з інтерпозицією графту гонадноївени (4).

рази підвищує ризик розвитку хронічної хвороби нирок у майбутньому [6 - 8]. Після операції померли 2 (8,7\%) хворих. У 1 хворої діагностована гостра перфорація дванадцятипалої кишки з подальшим розвитком у післяопераційному періоді синдрому поліорганної недостатності; у 1 хворого в ранньому післяопераційному періоді виникла гостра масивна кровотеча, у подальшому - перфорація ободової кишки з розвитком тяжкого сепсису. Обом хворим, які померли, була виконана нефректомія без аутотрансплантації, різниця між обома групами статистично незначуща $\left(\chi^{2}=0,47, \mathrm{p}>0,05\right)$.

\section{Обговорення}

Питання про необхідність нефректомії виникає доволі часто у разі хірургічного лікування неорганних заочеревинних пухлин. Істинної інвазії в структури нирки не виявляють у $73 \%$ хворих [7].

У даному дослідженні представлено перший в Україні досвід успішного виконання нефректомії еx vivo ex situ та аутотрансплантації нирки під час хірургічного лікування первинних місцево-розповсюджених та рецидивних солідних пухлин черевної порожнини та заочеревинного простору.

Мала вибірка та нетривалий період спостереження не дають змоги в повній мірі оцінити віддалені онкологічні та хірургічні результати.

\section{Висновки}

1.3 метою профілактики розвитку гострого ушкодження нирок та хронічної хвороби нирок у майбутньому можливість виконання аутотрансплантації нирки під час хірургічного лікування солідних пухлин черевної порожнини та заочеревинного простору, окрім первинного раку нирки, повинна бути розглянута щодо кожного хворого.

2. Аутотрансплантацію, яка дає змогу зберегти нирку та може бути виконана безпечно з прийнятними найближ- 
чими результатами, доцільно виконувати в спеціалізованих лікувальних закладах, де накопичено досвід в онковаскулярній хірургії.

\section{References}

1. Lopez-Cano M, Manas MJ, Hermosilla E, Espin E. Multivisceral resection for colon cancer: analysis of prognostic factors. Dig Surg. 2010 Aug;27(3):238-45. doi: 10.1159/000276974.

2. Larkin JO, O'Connell PR. Multivisceral resection for T4 or recurrent colorectal cancer. Dig Dis. 2012;30 (Suppl 2):96-101. doi: $10.1159 / 000342037$

3. Bonvalot S, Miceli R, Berselli M, Causeret S, Colombo C, Mariani L, Bouzaiene $\mathrm{H}$, et al. Aggressive surgery in retroperitoneal soft tissue sarcoma carried out at high-volume centers is safe and is associated with improved local control. Ann Surg Oncol. 2010 Jun;17(6):1507-14. doi: 10.1245/s10434-010-1057-5.

4. Pasquali S, Vohra R, Tsimopoulou I, Vijayan D, Gourevitch D, Desai A. Outcomes Following Extended Surgery for Retroperitoneal Sarcomas: Results from a UK Referral Centre. Ann Surg Oncol. 2015 Oct:22(11):3550-6. doi: 10.1245/s10434-015-4380-z.
5. Singer S, Antonescu CR, Riedel E, Brennan MF. Histologic subtype and margin of resection predict pattern of recurrence and survival for retroperitoneal liposarcoma. Ann Surg. 2003 Sep;238(3):358-70. doi: 10.1097/01.sla.0000086542.11899.38.

6. Schmid M, Krishna N, Ravi P, Meyer CP, Becker A, Dalela D, et al. Trends of acute kidney injury after radical or partial nephrectomy for renal cell carcinoma. Urol Oncol. 2016 Jul;34(7):293.e1-293.e10. doi: 10.1016/j.urolonc.2016.02.018.

7. Cho A, Lee JE, Kwon GY, Huh W, Lee HM, Kim YG, et al. Post-operative acute kidney injury in patients with renal cell carcinoma is a potent risk factor for new-onset chronic kidney disease after radical nephrectomy. Nephrol Dial Transplant. 2011 Nov;26(11):3496-501. doi: 10.1093/ndt/gfr094.

8. Hull MA, Niemierko A, Haynes AB, Jacobson A, Chen YL, DeLaney $\mathrm{TF}$, et al. Post-operative renal function following nephrectomy as part of en bloc resection of retroperitoneal sarcoma. J Surg Oncol. 2015 Jul;112(1):98-102. doi: 10.1002/jso.23949. 